Yayınlayan: Ankara Üniversitesi KASAUM

Adres: Kadın Sorunları Araştırma ve Uygulama Merkezi, Cebeci 06590 Ankara

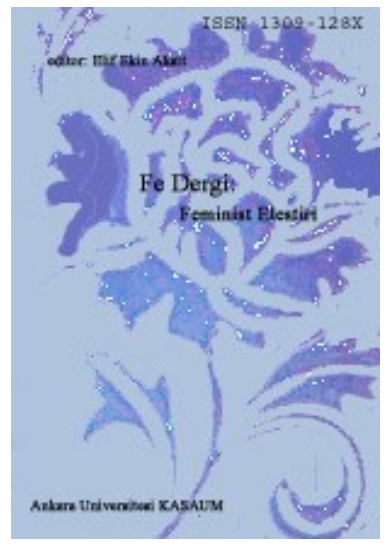

Fe Dergi: Feminist Eleştiri Cilt 3 Sayı 1

Erişim bilgileri, makale sunumu ve ayrıntılar için:

http://cins.ankara.edu.tr/

Badran ve İslamda Feminizm

Zehra Yllmaz

Çevrimiçi yayına başlama tarihi: 15 Haziran 2011

Bu makaleyi alıntılamak için: Zehra Yılmaz, "Badran ve İslamda Feminizm," Fe Dergi 3, no. 1 (2011), 108109.

URL: http://cins.ankara.edu.tr/badran.html

$\mathrm{Bu}$ eser akademik faaliyetlerde ve referans verilerek kullanılabilir. Hiçbir şekilde izin alınmaksızın çoğaltılamaz. 


\section{Badran ve İslamda Feminizm}

Zehra Yllmaz

Margot Badran, Feminism in Islam, Oneworld Publication, 2009.

İslam ve feminizm arasındaki ilişki daima gerilimli olmuştur. Bu gerilim her iki perspektifin savunucuları tarafından da beslenmektedir. İslamın, temelde kadın erkek eşitsizliğine dayandığını savunan ve çok eşli evlilik, örtünme gibi İslam pratiklerini feminist bir hareketin önündeki en temel engeller olarak görenler, feminizmi ve İslam'ı yanyana gelmesi imkansız iki farklı perspektif olarak değerlendirir. Bunun tam tersi İslamcılar ise İslam'da kadın erkek eşitliği sorunu olmadığı savından yola çıkarak, feminizmin İslam'ın özüne zarar verdiğini savunur. Böylece "feminizm ve İslam yanyana gelemez" argümanını başka bir boyutuyla İslamcilar da destekler.

Ortadoğu'daki-özellikle Mısır'daki-Müslüman kadınlar üzerine birçok araştırması bulunan Margot Badran, uzun yıllardır yazdığı çeşitli kitap ve makalelerle temelde yukarıda değindiğim varsayıma itiraz ediyor. 1991 yılından 2007 yılına kadar yaklaşık 16 yıl içinde Müslüman kadınlar üzerine yaptığı çalışmalardan seçtiği makaleleri bir kitapta toplayan Badran, son kitabı ile İslamcı feminist kadınlar hakkında bugüne kadar ürettiği yazıları bize derli toplu sunuyor.

2009 yılında yayınladığı "Feminism in Islam” adlı kitabında Badran, Feminizm ve İslam kavramlarının birbirine zıt olmadığını savunurken; İslam'ın diğer dinlerle karşılaştırıldığında kadın-erkek eşitliğine "Tanrının sözü" olarak değinen tek din olmasına rağmen bugün bunun tam tersi bir algılayışın egemen olmasını "ironik" olarak değerlendiriyor. İslamcı feminist kadınların itirazını tekrar ederek Badran da, Müslüman ülkelerdeki kadınların olumsuz koşullarda yaşamasının nedeninin İslam'dan değil, bu ülkelerde egemen olan patriarkal yapılardan kaynaklandığını düşünüyor.

Son kitabında Badran, öncelikle Mısır üzerine yaptığı çalışmalara yer veriyor. Mısır'dan başlayarak Türkiye, Malezya, Yemen gibi farklı örneklerle de Müslüman kadınların aktivistleşme sürecini ve feminizmle ilişkilerini açıklamaya çalışıyor. 14 makalenin bulunduğu kitap öncelikle Mısır'daki feminizm hareketi, ayrıca da Müslüman kadınların feminizm ile ilişkisi üzerine detaylı bir profil sunuyor.

Badran'ın kitabındaki makaleleri yatay olarak kesen argümanlar İslamcı feminist tartışmalar ve bu tartışmalara ilgi duyanlar açısından çok dikkat çekici. Margot Badran temelde İslamcı feminist hareketi "küresel bir söylem" olarak tanımlıyor. İslamcı feminizmi, Müslüman ülkelerdeki kadınların başlattığı, ama bugün dünyanın geri kalanını da etkileyen hatta belki de feminizmin yeniden tanımlanmasına neden olabilecek güçlü ve küresel bir söylem olarak değerlendiriyor. Yazar Hıristiyan olmasına rağmen, kendisini de İslamcı feminist olarak tanımliyor.

Badran'ın bu bağlamda İslamcı feminizme atfettiği en önemli değer, İslam'ın reforme edilmesi bakımından İslamcı feministlerin bugüne kadar bıraktığı ve bundan sonra bırakacağı etkiler. İslam'da reformun feminist bir perspektiften asıl İslamcı feminist kadınlar tarafından gerçekleştirildiğini savunan Badran, bu çabayı İslam'ı dönüştürmek değil tam tersi İslam'ın özüne dönmek olarak tanımlıyor (s.324-325).

Kitabında Ortadoğu'daki feminist hareketi "Seküler feminizm" ve "İslamcı feminizm" olmak üzere kendi içinde iki gruba ayıran Badran, sanıldığının aksine bu iki feminist hareketin birbirine zıt olmadığını çoğu noktada birbiri ile kesiştiklerini hatta birbirlerini beslediklerini ifade ediyor. Diğer taraftan etkisi ve argümanları bakımından İslamcı feminist hareketi, seküler hareketten daha radikal bulduğunu, İslamcı kadın hareketinin kadın-erkek eşitliği bağlamında Ortadoğu'nun eril yapısının çözülmesine daha önemli katkılar sağladığını iddia ediyor. İslamcı feminizmin Ortadoğu feminist hareketine en önemli katkısının da, seküler feminizmin yapamadığı özel alan ve kamusal alan ayrımını ortadan kaldırması olarak tanımlıyor. Ayrıca kitabında Badran, İslamcı feminizmin daha evrensel bir dil üretmesi bakımından da, milliyetçilik ile bağlarını koparmakta güçlük çeken seküler feminizmden daha ileride olduğunu iddia ediyor.

Bu noktada çoğu tartışmada gündeme gelen İslamcı feminist kadınların kendilerini "feminist" olarak tanımlamaktan çekinmeleri mevzusuna Badran da değiniyor. Öncelikle Badran, hiçbir hareketin önce tanımlanıp, sonra başlamadığına dikkat çekiyor. Daha sonra da, "bazı hareketler taraftarları tarafindan, bazı hareketler de başkaları tarafından tanımlanır; İslamcı feminist hareket de başkaları tarafından tanımlanmış bir harekettir" (s. 325) diye ekliyor. Badran, feminizmin batılı bir hareket olarak görülmesi ve Müslüman toplumun geleneksel yapısında tahribat yaratacağını düşünmeleri nedeniyle Ortadoğu'daki İslamcı kadınların hareketlerini ya da kendilerini "feminist" olarak tanımlamaktan çekindiklerini tespit ediyor. Fakat, bu çekincenin hareketi dişarıdan takip edenler açısından onları "feminist" olarak tanımlamaya engel teşkil etmediğini de ayrıca belirtiyor. 
Özetle Badran, artık daha tekil bir feminizm değil farklılıklara daha açık hatta daha muhalif bir feminizm tanımı yapmak gerekliliğine inanıyor. Bu anlamda İslamcı feminist kadınların feminizme katkısını çok önemsiyor. Diğer taraftan, İslamcı feminist kadınların hem modernizmi tanımlamak hem de İslam'1 reforme etmek açısından dikkate değer bir hareket olduğuna da işaret ediyor. Bu üç boyutuyla İslamcı feminist hareketin önümüzdeki yıllarda çok daha radikal bir etki yaratacağını öngörüyor.

Badran'ın son kitabı İslamcı feminizmin tarihsel olarak nasıl geliştiğini, hem ortaya çıktı̆̆ı topraklar üzerinde hem de küresel düzlemde ne tür etkiler bıraktığını ve yerelden küresele doğru hareketin geçirdiği evrimi derinlemesine ve detaylı olarak okuyucuya sunuyor. Kitap sadece İslamcı kadınların argümanlarını ve tarih silsilesini takip etmek bakımından değil, feminizmin sınırları ve sınırlılıkları tartışmasına katkısı açısından önemli bir açılım sağlıyor. 